\title{
ОСОБЛИВОСТІ КЛІНІЧНОГО ПЕРЕБІГУ ГАСТРОЕЗОФАГЕАЛЬНОЇ РЕФЛЮКСНОЇ ХВОРОБИ У ЛЬВІВСЬКОМУ РЕГІОНІ
}

\section{Львівський національний медичний університет імені Данила Галицького}

๑М. Яхницька

РЕЗЮМЕ. Гастроезофагеальна рефлюксна хвороба (ГЕРХ) - найпоширеніша патологія сучасної гастроентерології, що завдає значних економічних та соціальних збитків, порушує якість життя людей.

Мета дослідження - вивчити клінічний перебіг гастроезофагеальної рефлюксної хвороби у Львівському регіоні.

Матеріал і методи. Проводили анкетування, ендоскопічне обстеження верхніх відділів шлунково-кишкового тракту, cito test® H. Pylori Ag фірми Pharmasco® для діагностики гелікобактерної інфекції.

Результати. Проаналізовано результати спостережень за 102 пацієнтами з ГЕРХ: серед них було 48 (47,1 \%) жінок та 54 (52,9 \%) чоловіки. Середній вік жінок становив $(48 \pm 2,11)$ року, чоловіків - $(37,7 \pm 1,65)$ року. У 73,5 \% обстежених діагностовано ендоскопічно позитивну форму ГЕРХ, тоді як 26,5 \% не мали ерозивно-виразкових змін слизової оболонки стравоходу. Вивчення зв'язку способу життя у хворих на ГЕРХ показало, що нерегулярне харчування та куріння сприяють розвитку захворювання. Аналіз основних скарг показав: у 37,2 \% хворих печія щоденна, періодичну печію 3-4 рази на тиждень відмічали 62,7 \% пацієнтів. Відрижка та ранкове блювання мали місце у 59,8 та 16,7 \% хворих відповідно. Нудоту відмічали 37,2 \% обстежених. На неприємний присмак у роті скаржилися 35,3 \% пацієнтів. Біль в епігастрії спостерігали у 53,9 \% обстежених. 27,5 \% хворих на ГЕРХ були інфіковані Н. pуlori.

Висновки. 1. Встановлено, що ендоскопічно негативна форма ГЕРХ у 4 рази частіше діагностується в жінок, тоді як ерозивні зміни слизової стравоходу вдвічі переважають серед осіб чоловічої статі. 3'ясовано, що найчастіше ГЕРХ діагностували в осіб молодого та середнього віку (48,1 та 19,1 \% відповідно).

2. Показано, що факторами ризику розвитку ГЕРХ $\epsilon$ нерегулярне харчування та куріння. Натомість гелікобактерна інфекція не асоціюється з ГЕРХ незалежно від ендоскопічної картини.

3. Встановлено, що щоденна печія, нудота та неприємний присмак частіше зустрічаються у пацієнтів 3 ендоскопічно негативною ГЕРХ (55,6, 62,9 та 77,7 \% відповідно), поєднання періодичної печії, відрижки та болю в епігастрії дозволяє запідозрити наявність ерозивно-виразкових змін слизової оболонки стравоходу.

КлючОВІ СлОВА: гастроезофагеальний рефлюкс; клінічні прояви; гелікобактерна інфекція.

Вступ. В останнє десятиріччя значно активізувалося вивчення гастроезофагеальної рефлюксної хвороби (ГЕРХ). Це зумовлено постійним зростанням поширеності ГЕРХ та значною зацікавленістюданоюпатологією середвченихіпрактичних лікарів. Коли перші шукають нові етіологічні чинники, домінуючі патогенетичні ланки, то інших цікавлять клінічні прояви та лікування $[1,2,7]$. Проте в клінічній практиці лікарі недостатньо обізнані з проявами атипового перебігу хвороби, а також недостатньо оцінюють клінічні прояви ГЕРХ. Все це потребує постійного детального вивчення особливостей перебігу клініки ГЕРХ.

Клінічні скарги пацієнтів із ГЕРХ складаються з типових стравохідних і позастравохідних ознак. Стравохідні скарги зумовлені впливом кислоти і пепсину на слизову оболонку стравоходу. До них належать: печія, кисла відрижка, регургітація, дисфагія, ретростернальний біль і біль в епігастрії $[3,4]$. Позастравохідні симптоми ГЕРХ поділяють на 4 основні групи: оториноларингологічні (ларингіт, фарингіт, сухість, дертя в горлі, отит); бронхолегеневі (стійкий кашель, підкашлювання, осиплість голосу, аспіраційна пневмонія, бронхі- альна астма); кардіальні (біль у ділянці серця, аритмії, тахікардія, рефлекторне центральне апное); стоматологічні (витончення зубної емалі, рецидивний карієс, афтозний стоматит, періодонтит) [5]. Було відзначено, що у 50 \% випадків причиною болю (не зумовленого ураженням серця) в лівій половині грудної клітки $\epsilon$ ГЕРХ, а потрапляння рефлюктанту в просвіт бронхів здатне провокувати виникнення бронхоспазму [6].

Печія $\epsilon$ наслідком збудження хеморецепторів слизової оболонки стравоходу рефлюктантом. За наявності у пацієнта печії для експрес-діагностики вірогідної рефлюксної хвороби рекомендоване застосування ГEPX-опитувальника $[7,8]$. Якщо пацієнт відповідає «так» на всі поставлені питання, то ймовірність наявності ерозивного езофагіту при ендоскопії або виявлення патологічного рефлюксу при добовій рН-метрії (або їх поєднанні) досягає 85 \%. Тяжкість печії можна оцінювати за допомогою опитувальника, основаного на бальній оцінці наявності та вираження суб'єктивних відчуттів хворого, пов'язаних з печією $[9,10]$. Доведено, що у США щодня симптоми ГЕРХ відзначають 4-10\% осіб, щотижня 20-30 \% і щомісяця близько 
Огляди літератури, оригінальні дослідження, погляд на проблему, ювілеї

$50 \%$ опитаних [11]. Зокрема, досліджено, що якість життя пацієнтів із ГЕРХ нижча, ніж у хворих з нелікованими дуоденальною виразкою, стенокардією, серцевою недостатністю та гіпертензією [12]. Серед 20 \% осіб, які відчувають печію щодня, близько половини страждають через це від безсоння, відзначають зниження працездатності, дратівливість та нервові порушення [13].

В Україні типові для ГЕРХ скарги (печію, кисле зригування, дисфагію) щоденно мають 3,3 \% популяції, раз на тиждень - 17,3 \% пацієнтів. При цьому частота цих скарг у жінок і чоловіків майже однакова, але пік захворюваності на ГЕРХ у перших припадає на вік 17-29, а в останніх - на 2059 років. Атипові скарги (нічні кардіалгію, задуху, кашель) мають 13,1 \% дорослого населення незалежно від статі [14].

На території Львівської області проводили дослідження, де було вивчено клінічні особливості перебігу захворювань стравоходу в пацієнтів, які тривало приймали нестероїдні протизапальні препарати. Доведено, що захворювання стравоходу виявляється найчастіше при тривалості ревматологічних захворювань 11-20 років. Також досліджено, що помірна та виражена печія турбують пацієнтів ревматологічного профілю з ерозивною ГЕРХ та функціональною печією майже з однаковою частотою [15].

При власному вивченні поширеності ендоскопічно позитивної форми ГЕРХ було встановлено, що дана патологія частіше зустрічається в чоловіків. Окрім того, доведено, що ерозивні зміни слизової оболонки стравоходу часто поєднуються з іншими захворюваннями шлунково-кишкового каналу (ШКК) $[16,17]$.

Таким чином, існує ряд чинників, які не дозволяють оцінити реальні масштаби поширеності ГЕРХ. Насамперед це зумовлено тим, що для більшості пацієнтів печія не є причиною звернення до лікаря. Іншим важливим фактором $є$ складність диференційної діагностики ГЕРХ у пацієнтів із супутньою патологією. Це зумовлено наявністю не- специфічних скарг, нетиповим перебігом захворювання, відсутністю швидких діагностичних тестів. Все це потребує постійного детального вивчення особливостей перебігу клініки ГЕРХ.

Мета дослідження - вивчити особливості клінічного перебігу гастроезофагеальної рефлюксної хвороби у Львівському регіоні.

Матеріал і методи. Проведено комплексне обстеження 102 пацієнтів, які лікувалися в КНП «Новояворівська районна лікарня №1 імені Ю. Липи». Усім хворим здійснювали анкетування за допомогою модифікованої анкети Лікерта: визначали типові (печія, відрижка кислим) для ГЕРХ скарги.

Ендоскопічне обстеження верхніх відділів шлунково-кишкового каналу виконували апаратом Pentax 15000. Ендоскопічними критеріями неерозивної ГЕРХ вважали поєднання недостатності кардіального жому і/або почервоніння слизової оболонки, і/або закидання шлункового/дуоденального вмісту в нижній відділ стравоходу; ерозивної ГЕРХ - ерозивно-виразкові пошкодження слизової оболонки стравоходу [18].

Фекальний антигенний cito test $®$ H. Pylori Ag фірми Pharmasco® використовували для діагностики гелікобактерної інфекції.

Діагноз «ГЕРХ» встановлювали відповідно до протоколу надання медичної допомоги № 943 від 31 жовтня 2013 року: наявність у пацієнтів скарг на щоденну а6о періодичну печію 3-4 рази на тиждень та/або виявлення ерозивних змін слизової оболонки стравоходу під час ендоскопічного обстеження ШКК.

Комп'ютерну обробку даних проводили за допомогою програми Microsoft Excel. Статистично достовірними вважали дані при р<0,05.

Результати й обговорення. Проаналізовано анкети 102 пацієнтів із ГЕРХ, серед них 48 (47,1\%) жінок та 54 (52,9 \%) чоловіки. Середній вік жінок становив $(48 \pm 2,11)$ року, чоловіків - $(37,7 \pm$ $1,65)$ року.

Гендерний розподіл хворих на ГЕРХ представлено в таблиці 1.

Таблиця 1. Розподіл ендоскопічно позитивної та ендоскопічно негативної форм ГЕРХ залежно від статі

\begin{tabular}{|l|c|c|c|c|}
\hline \multirow{2}{*}{ Стать } & \multicolumn{2}{|c|}{ Неерозивна ГЕРХ $(\mathrm{n}=27)$} & \multicolumn{2}{c|}{ Ерозивна ГЕРХ $(\mathrm{n}=75)$} \\
\cline { 2 - 5 } & хворих & $\%$ & хворих & 34,7 \\
\hline Жінки & 22 & 81,5 & 26 & 65,3 \\
\hline Чоловіки & 5 & 18,5 & 49 & \\
\hline
\end{tabular}

Як видно з таблиці 1, у жінок з однаковою кількістю випадків зустрічаються обидві форми ГЕРХ. Аналізуючи структуру ендоскопічно негативної форми ГЕРХ, встановлено що 81,5 \% становили жінки, 18,5 \% чоловіки. Серед хворих з ендоскопічно позитивною формою було 34,7 та
65,3 \% жінок і чоловіків відповідно. Співвідношення чоловіків до жінок у групі з ерозивними змінами в стравоході становило 1,9:1, у групі з неерозивною ГЕРХ - 1:4,4.

Аналіз вікової структури у хворих на ГЕРХ наведено в таблиці 2. 
Огляди літератури, оригінальні дослідження, погляд на проблему, ювілеї

Таблиця 2. Розподіл ендоскопічно негативної та ендоскопічно позитивної форм ГЕРХ у різних вікових категоріях

\begin{tabular}{|c|c|c|c|c|c|c|c|c|}
\hline \multirow[t]{2}{*}{ Вік пацієнтів } & \multicolumn{2}{|c|}{$\begin{array}{c}\text { Ендоскопічно } \\
\text { негативна (ЕН) форма } \\
(n=18)\end{array}$} & \multicolumn{2}{|c|}{$\begin{array}{c}\text { Ендоскопічно } \\
\text { позитивна (ЕП) форма } \\
(n=26)\end{array}$} & \multicolumn{2}{|c|}{$\begin{array}{c}\text { ЕН та захворювання } \\
\text { верхніх відділів ШКК } \\
(n=9)\end{array}$} & \multicolumn{2}{|c|}{$\begin{array}{c}\text { ЕП та захворювання } \\
\text { верхніх відділів ШКК } \\
(\mathrm{n}=49)\end{array}$} \\
\hline & хворих & $\%$ & хворих & $\%$ & хворих & $\%$ & хворих & $\%$ \\
\hline $18-25$ & 4 & 22,2 & 2 & 7,7 & - & - & 2 & 4,1 \\
\hline $25-44$ & 8 & 44,4 & 3 & 11,5 & 3 & 3,3 & 24 & 8,9 \\
\hline $45-60$ & 6 & 33,4 & 18 & 69,2 & 6 & 6,7 & 16 & 2,6 \\
\hline $61-75$ & - & - & 3 & 11,6 & - & - & 7 & 4,4 \\
\hline
\end{tabular}

Отже, у віці 18-25 років ендоскопічно позитивна та ендоскопічно негативна форми ГЕРХ однаково часто зустрічаються як у чоловіків, так і в жінок. 84,3 \% обстежених були молодого віку, з них 55,1\% осіб, окрім ерозивних дефектів слизової оболонки стравоходу, мали ще й ураження верхніх відділів ШКК. У віці 45-60 років у 2,4 раза частіше виявляють ГЕРХ серед осіб жіночої статі, причому 62,5 \% з них хворіють на ерозивну форму ГЕРХ. У чоловіків даної вікової категорії спо- стерігали спорадичні випадки ізольованого ураження стравоходу. Виявлено, що у віці понад 61 рік на ендоскопічно позитивну форму ГЕРХ хворіли лише жінки.

Аналіз зв'язку між патологією стравоходу та способом життя (характер харчування, шкідливі звички) наведено в таблиці 3.

Як видно з таблиці 3, усі пацієнти нерегулярно та неправильно харчуються. 84,0 \% обстежених з ЕП ГЕРХ та 44,4 \% пацієнтів з ЕН ГЕРХ курили.

Таблиця 3. Зв'язок способу життя із виникненням патології стравоходу

\begin{tabular}{|l|c|c|c|c|}
\hline \multirow{2}{*}{ Особливості перебігу } & \multicolumn{2}{|c|}{ Ерозивна ГЕРХ $(\mathrm{n}=75)$} & \multicolumn{2}{c|}{ Неерозивна ГЕРХ (n=27) } \\
\cline { 2 - 5 } & хворих & $\%$ & хворих & $\%$ \\
\hline Нерегулярне харчування & 75 & 100,0 & 27 & 100,0 \\
\hline Куріння & 63 & 84,0 & 12 & 44,4 \\
\hline Зловживання алкоголем & 2 & 2,7 & 0 & 0 \\
\hline
\end{tabular}

Аналіз основних симптомів ГЕРХ залежно від змін слизової оболонки стравоходу, виявлених під час ендоскопічного обстеження, представлено в таблиці 4.

Таблиця 4. Поширеність основних скарг у пацієнтів із ГЕРХ

\begin{tabular}{|c|c|c|c|c|c|}
\hline \multirow{2}{*}{\multicolumn{2}{|c|}{ Скарги }} & \multicolumn{2}{|c|}{ Ендоскопічно негативна форма ( $n=27)$} & \multicolumn{2}{|c|}{ Ендоскопічно позитивна форма $(n=75)$} \\
\hline & & хворих & & хворих & $\%$ \\
\hline \multirow{2}{*}{ Печія } & Щоденна & 15 & 55,6 & 23 & 30,6 \\
\hline & 3-4 рази на тиждень & 12 & 44,4 & 52 & 69,3 \\
\hline \multicolumn{2}{|c|}{ Відрижка } & 14 & 51,8 & 47 & 62,6 \\
\hline \multicolumn{2}{|c|}{ Нудота } & 17 & 62,9 & 21 & 28 \\
\hline \multicolumn{2}{|c|}{ Ранкове блювання } & 5 & 18,5 & 12 & 16 \\
\hline \multicolumn{2}{|c|}{ Неприємний присмак у роті } & 21 & 77,7 & 15 & 20 \\
\hline \multicolumn{2}{|c|}{ Біль в епігастрії } & 9 & 33,3 & 49 & 65,3 \\
\hline
\end{tabular}

Отже, аналіз показав, що у 55,6 \% пацієнтів 3 ЕН ГЕРХ спостерігали печію щоденно, а 69,3 \% хворих з ерозивно-виразковими змінами слизової стравоходу відмічали печію 3-4 рази на тиждень. Відрижка та ранкове блювання майже з однаковою частотою зустрічаються при двох формaХ ГЕРХ. Нудоту 3 ЕН ГЕРХ та ЕП ГЕРХ спостерігали у 62,9 та 28,0 \% випадках відповідно. На неприємний присмак у роті в 3 рази частіше скаржилися пацієнти без ураження слизової оболонки стравоходу. Біль в епігастрії мав місце у
65,3 \% хворих з ЕП ГЕРХ на противагу 33,3 \% паці$\epsilon$ нтів з ЕН ГЕРХ.

Наявність/відсутність гелікобактерної інфекції у пацієнтів із ГЕРХ наведено в таблиці 5.

Як видно з таблиці 5, у кожного п'ятого паці$\epsilon$ нта з ендоскопічно негативною формою ГЕРХ $\epsilon$ інфікованість $H$. pylori. Серед хворих, які мали ерозивні зміни слизової оболонки стравоходу, інфекцію H. pylori виявлено у 30,7 \% осіб.

Таким чином, ендоскопічно негативна форма ГЕРХ більш поширена у жінок середнього віку, 
Огляди літератури, оригінальні дослідження, погляд на проблему, ювілеї

Таблиця 5. Зв'язок ГЕРХ із гелікобактерною інфекцією

\begin{tabular}{|l|c|c|c|c|}
\hline \multirow{2}{*}{ Н. pyloгу } & \multicolumn{2}{|c|}{ Ендоскопічно негативна форма ГЕРХ $(\mathrm{n}=27)$} & \multicolumn{2}{c|}{ Ендоскопічно позитивна форма ГЕРХ ( $\mathrm{n=75)}$} \\
\cline { 2 - 5 } & хворих & $\%$ & хворих & $\%$ \\
\hline Наявність & 5 & 18,5 & 23 & 30,7 \\
\hline Відсутність & 22 & 72,5 & 52 & 69,3 \\
\hline
\end{tabular}

тоді як ерозивні зміни слизової оболонки стравоходу частіше діагностували серед чоловіків молодого віку. Основними факторами ризику розвитку ГЕРХ були нерегулярне харчування та куріння. Аналіз поширеності типових скарг показав, що у кожного пацієнта з ГЕРХ є свій індивідуальний набір скарг. Проте поєднання щоденної печії, нудоти та неприємного запаху з рота має місце й у тих пацієнтів, в яких не виявлено змін слизової оболонки стравоходу при ендоскопічному обстеженні. Коли пацієнт скаржиться на періодичну печію, відрижку та біль в епігастрії, це дозволяє запідозрити ендоскопічно позитивну форму ГЕРХ. Окрім того, чітко доведено, що ГЕРХ, незалежно від ендоскопічної картини, не асоційована з гелікобактерною інфекцією.

Ймовірно, поєднання декількох типових скарг у хворих на ГЕРХ має відповідати ерозивній та неерозивній формам захворювання. Втім, щоб 3 більшим відсотком ймовірності це стверджувати, потрібно збільшити кількість респондентів, зокрема з неерозивною ГЕРХ. Окрім цього, враховувати особливості екології території, на якій живуть пацієнти. Отже, вивчення та прогнозування різних клі- нічних проявів ГЕРХ є одним з актуальних питань у клініці внутрішніх хвороб.

Висновки. 1. Встановлено, що ендоскопічно негативна форма ГЕРХ у 4 рази частіше діагностується у жінок, тоді як ерозивні зміни слизової стравоходу вдвічі переважають серед осіб чоловічої статі. З'ясовано, що найчастіше ГЕРХ діагностували в осіб молодого та середнього віку $(48,1$ та 19,1 \% відповідно).

2. Показано, що факторами ризику розвитку ГEPX $\epsilon$ нерегулярне харчування та куріння. Натомість гелікобактерна інфекція не асоціюється 3 ГЕРХ незалежно від ендоскопічної картини.

3. Встановлено, що щоденна печія, нудота та неприємний присмак частіше зустрічаються у пацієнтів з ендоскопічно негативною ГЕРХ $(55,6$, $62,9,77,7$ \% відповідно), поєднання періодичної печії, відрижки та болю в епігастрії дозволяє запідозрити наявність ерозивно-виразкових змін слизової оболонки стравоходу.

Перспективи подальших досліджень. Вдосконалення діагностичного алгоритму виявлення ГЕРХ шляхом запровадження швидких та економічно обґрунтованих неінвазивних скринінгових тестів.

\section{ЛІТЕРАТУРА}

1. Бабак О. Я. ГЕРХ. Від теорії до практики / О. Я. Бабак // Сучасна гастроентерологія. - 2014. - № 4 (78). С. $38-44$.

2. Бабак М. О. Поширеність типових та атипових проявів гастроезофагеальної рефлюксної хвороби / М. О. Бабак // Укр. терапевт. журн. - 2011. - № 2. - С. 33-37.

3. Blondeau K. Treatment of gastroesophageal reflux disease:the new kids to block / K. Blondeau // Neurogastroenterol. Motil. - 2010. - Vol. 22. - P. 836-840.

4. Стоматологічні прояви гастроезофагеальної рефлюксної хвороби у дітей та дорослих. Огляд літератури / Р. С. Назарян, Н. Ю. Ємельянова, О. В. Карнаух, Т. Г. Хмиз // Профілактична та дитяча стоматологія. 2013. - № 2 (9). - С. 34-39.

5. Звенигородская Л. А. Терапия гастроэзофагеальной рефлюксной болезни при ишемической болезни сердца / Л. А. Звенигородская, А. А. Чурикова // Клин. геронт. - 2012. - № 18. - С. 48-51.

6. Каменір В. М. Динаміка рівня стабільних метаболітів оксиду азоту і мелатоніну у пацієнтів з гастроезофагеальною рефлюксною хворобою у поєднанні з хронічним обструктивним захворюванням легень на тлі лікування мелатоніном / В. М. Каменір // Сучасна гастроентерологія. - 2010. - № 4. - С. 61-66.

7. Kahrilas P. J. Review article: gastroesophageal reflux disease as a functional gastrointestinal disorder / P. J. Kahrilas // Aliment. Pharmacol Iher. - 2004. - Vol. 20 (Suppl.). - P. 50-55.

8. Kellerman R. Gastroesophageal reflux disease / R. Kellerman, T. Kintanar // Prim. Care. - 2017. - Vol. 44 4). P. 561-573. doi: 10.1016/j.pop.2017.07.001. Epub 2017 Oct 5. Review. PubMed PMID: 29132520.

9. Kseneva S. I. Discoordination of autonomic support of functions in the pathogenesis gastroesophageal reflux disease / S. I. Kseneva, E. V. Borodulina, V. V. Udut // Bull. Exp. Biol. Med. - 2018. doi: 10.1007/s10517-018-4279-3. [Epub ahead of print] PubMed PMID:30450517.

10. Маев И. В. Гастроэзофагеальная рефлюксная болезнь - болезнь XXI века / И. В. Маев // Лечащий врач. - 2004. - № 4. - С. 10-14.

11. Вдовиченко В. І. Кардіологічні симптоми гастроезофагеальної рефлюксної хвороби у пацієнтів із цукровим діабетом 2 типу / В. І. Вдовиченко, Я. П. Свердан // Сучасна гастроентерологія. - 2013. -№ 3 (71). - С. 110-114.

12. Палій І. Г. Поширення ГЕРХ серед хворих з патологією органів травлення, провокуючі чинники та ефективність блокаторів $\mathrm{H}+/ \mathrm{K}+\mathrm{ATФази} \mathrm{(за} \mathrm{результатами} \mathrm{ан-}$ кетування амбулаторних хворих) / І. Г. Палій, С. В. Заїка, 
Огляди літератури, оригінальні дослідження, погляд на проблему, ювілеї

А. Г. Янковецька // Сучасна гастроентерологія. - 2014. № 4 (78). С. 38-44.

13. Острогляд А. В. Перший досвід вивчення епідеміології гастроезофагеальної рефлюксної хвороби в Україні / А. В. Острогляд // Сучасна гастроентерологія. 2006. - № 1 (27). - С. 30-32.

14. Бабак М. О. Гендерні особливості поширеності гастроезофагеальної рефлюксної хвороби / М. О. Бабак // Сучасна гастроентерологія. - 2011. - № 3. С. $11-16$.

15. Бичков М. А. Клінічні особливості перебігу захворювань стравоходу у пацієнтів ревматологічного профілю / М. А. Бичков //Український ревматологічний журнал. -2011 . - № 3. С. 75-78.

\section{REFERENCES}

1. Babak, O.Ya. (2014). HERKh. Vid teorii do praktyky [GERD. From theory to practice]. Suchasna hastroenterolohiia - Modern Gastroenterology, 4 (78), 38-44 [in Ukrainian].

2. Babak, M.O. (2011). Poshyrenist typovykh ta atypovykh proiaviv hastroezofahealnoi refliuksnoi khvoroby [The prevalence of typical and atypical manifestations of gastroesophageal reflux disease]. Ukr. terapevt. zhurn. Ukrainian Therapeutic Journal, 2, 33-37 [in Ukrainian].

3. Blondeau, K. (2010). Treatment of gastroesophageal reflux disease:the new kids to block. Neurogastroenterol. Motil., 22, 836-840.

4. Nazarian, R.S., Yemelianova, N.Yu., Karnaukh, O.V., \& Khmyz, T.H. (2013). Stomatolohichni proiavy hastroezofahealnoi refliuksnoi khvoroby u ditei ta doroslykh. Ohliad literatury [Dental displays of gastroesophageal reflux disease in children and adults. Literature review]. Profilaktychna ta dytiacha stomatolohiia - Preventive and Pediatric Dentistry, 2 (9), 34-39 [in Ukrainian].

5. Zvenigorodskaya, L.A., \& Churikova, A.A. (2012). Terapiya gastroezofagelnoy reflyuksnoy bolezni pri ishemicheskoy bolezni serdtsa [Therapy of gastroesophageal reflux disease in coronary heart disease.]. Klin. geront. Clinical Gerontology, 18, 48-51 [in Russian].

6. Kahrilas, P.J. (2004). Review article: gastroesophageal reflux disease as a functional gastrointestinal disorder. Aliment. Pharmacol Iher., 20 (Suppl), 50-55.

7. Kamenir, V.M. (2010). Dynamika rivnia stabilnykh metabolitiv oksydu azotu i melatoninu u patsiientiv z hastroezofahalnoiu refliuksnoiu khvoroboiu u poiednanni z khronichnym obstruktyvnym zakhvoriuvanniam lehen na tli likuvannia melatoninom [Dynamics of the level of stable metabolites of nitric oxide and melatonin in patients with gastroesophageal reflux disease in combination with chronic obstructive pulmonary disease on the background of treatment with melatonin]. Suchasna hastroenterolohiia Modern Gastroenterology, 4, 61-66 [in Ukrainian].

8. Kellerman, R., \& Kintanar, T. (2017). Gastroesophageal reflux disease. Prim. Care, 44 (4), 561-573. doi: 10.1016/j.pop.2017.07.001. Epub 2017 Oct 5. Review. PubMed PMID: 29132520.

9. Kseneva, S.I., Borodulina, E.V., \& Udut, V.V. (2018). Discoordination of autonomic support of functions in the pathogenesis gastroesophageal reflux disease. Bull. Exp.
16. Бичков М. А. Поширеність гастроезофагеальної рефлюксної хвороби за даними ендоскопічних досліджень / М. А. Бичков, М.М.Яхницька // Здобутки клінічної і експериментальної медицини. - 2017. - № 2. C. 38-43.

17. Гендерні та вікові особливості ендоскопічно позитивної форми гастроезофагеальної рефлюксної хвороби / М. А. Бичков, Я. М. Савицький, Я. Б. Швидкий, М. М. Яхницька // Актуальні проблеми сучасної медицини. - 2017. - № 17 (4). - С. 72-76.

18. Ендоскопічна діагностика гастроезофагеальної рефлюксної хвороби / О. О. Крилова, Т. В. Майкова, В. М. Кутняк, С. Ю. Єршова // Сучасна гастроентерологія. - 2016. - № 6 (92). - С. 109-118.

Biol. Med. doi: 10.1007/s10517-018-4279-3. [Epub ahead of print] PubMed PMID:30450517.

10. Maev, I.V. (2004). Gastroezofagelnaya reflyuksnaya bolezn - bolezn XXI veka [Gastroesophageal reflux disease - a disease of the XXI century]. Lechashchii vrach - Attending Doctor, 4, 10-14 [in Russian].

11. Vdovychenko, V.I., \& Sverdan, Ya.P. (2013). Kardiolohichni symptomy hastroezofahealnoi refliuksnoi khvoroby u patsiientiv iz tsukrovym diabetom 2 typu [Cardiological symptoms of gastroesophageal reflux disease in patients with diabetes mellitus type 2]. Suchasna hastroenterolohiia - Modern Gastroenterology, 3 (71), 110-114 [in Ukrainian].

12. Palii, I.H., Zaika, S.V., \& Yankovetska, A.H. (2014). Poshyrennia HERKh sered khvorykh z patolohiieiu orhaniv travlennia, provokuiuchi chynnyky ta efektyvnist blokatoriv $\mathrm{N}+/ \mathrm{K}+\mathrm{ATFazy}$ (za rezultatamy anketuvannia ambulatornykh khvorykh) [Distribution of GERD among patients with pathology of digestive organs, provocative factors and the effectiveness of $\mathrm{N}+/ \mathrm{K}+$ ATPase blockers (based on the results of the survey of ambulatory patients)]. Suchasna hastroenterolohiia - Modern Gastroenterology, 4 (78), 38-44 [in Ukrainian].

13. Ostrohliad, A.V. (2006). Pershyi dosvid vyvchennia epidemiolohii hastroezofahealnoi refliuksnoi khvoroby $v$ Ukraini [The first experience of epidemiology of gastroesophageal reflux disease in Ukraine]. Suchasna hastroenterolohiia - Modern Gastroenterology, 1 (27), 30-32 [in Ukrainian].

14. Babak, M.O. (2011). Henderni osoblyvosti poshyrenosti hastroezofahealnoi refliuksnoi khvoroby [Gender features of the prevalence of gastroesophageal reflux disease]. Suchasna hastroenterolohiia - Modern Gastroenterology, 3, 11-16 [in Ukrainian].

15. Bychkov, M.A. (2011). Klinichni osoblyvosti perebihu zakhvoriuvan stravokhodu u patsiientiv revmatolohichnoho profiliu [Clinical features of the course of diseases of the esophagus in patients with rheumatoid profile]. Ukrainskyi revmatolohichnyi zhurnal - Ukrainian Rheumatological Journal, 3, 75-78 [in Ukrainian].

16. Bychkov, M.A., \& Yakhnytska, M.M. (2017). Poshyrenist hastroezofahealnoi refliuksnoi khvoroby za danymy endoskopichnykh doslidzhen [Prevalence of gastroesophageal reflux disease according to endoscopic studies]. Zdo- 
Огляди літератури, оригінальні дослідження, погляд на проблему, ювілеї

butky klinichnoi i eksperymentalnoi medytsyny - Achievements of Clinical and Experimental Medicine, 2, 38-43 [in Ukrainian].

17. Bychkov, M.A., Savytskyi, Ya.M., Shvydkyi, Ya.B., \& Yakhnytska, M.M. (2017). Henderni ta vikovi osoblyvosti endoskopichno pozytyvnoi formy hastroezofahealnoi refliuksnoi khvoroby [Gender and age characteristics of the endoscopically positive form of gastroesophageal reflux

disease]. Aktualni problemy suchasnoi medytsyny - Actual Problems of Modern Medicine, 17 (4), $72-76$ [in Ukrainian].

18. Krylova, O.O., Maikova, T.V., Kutniak, V.M., \& Yershova, S.lu. (2016). Endoskopichna diahnostyka hastroezofahealnoi refliuksnoi khvoroby [Endoscopy diagnosis of gastroesophageal reflux pain]. Suchasna hastroenterolohiia - Modern Gastroenterology, 6 (92), 109-118 [in Ukrainian].

\title{
ОСОБЕННОСТИ КЛИНИЧЕСКОГО ТЕЧЕНИЯ ГАСТРОЭЗОФАГЕАЛЬНОЙ РЕФЛЮКСНОЙ БОЛЕЗНИ ВО ЛЬВОВСКОМ РЕГИОНЕ
}

ОМ. Яхницкая

\author{
Львовский национальный медицинский университет имени Данила Галицкого
}

РЕЗЮМЕ. Гастроэзофагеальная рефлюксная болезнь (ГЭРБ) - самая распространенная патология современной гастроэнтерологии, которая наносит значительный экономический и социальный убыток, нарушает качество жизни людей.

Цель - изучить клиническое течение гастроэзофагеальной рефлюксной болезни во Львовском регионе.

Материал и методы. Проводили анкетирование, эндоскопическое обследование верхних отделов желудочно-кишечного тракта, cito test@ H. Pylori Ag фирмы Pharmasco® для диагностики хеликобактерной инфекции.

Результаты. Проанализированы результаты наблюдений за 102 пациентами с ГЭРБ: среди них было 48 $(47,1 \%)$ женщин и 54 (52,9 \%) мужчины. Средний возраст женщин составил $(48 \pm 2,11)$ года, мужчин $(37,7 \pm 1,65)$ года. В 73,5 \% обследованных диагностирована эндоскопически позитивная форма ГЭРБ, тогда как 26,5 \% не имели эрозивно-язвенных изменений слизистой оболочки пищевода. Изучение связи образа жизни у больных ГЭРБ показало, что нерегулярное питание и курение способствуют развитию заболевания. Анализ жалоб показал: у 37,2 \% больных изжога ежедневная, периодическую изжогу 3-4 раза в неделю отмечали 62,7 \% пациентов. Отрыжка и утренняя рвота наблюдалась у 59,8 и 16,7 \% больных соответственно. Тошноту отмечали 37,2 \% обследованных. На неприятный привкус во рту жаловались 35,3 \% пациентов. Боль в эпигастрии наблюдалась у 53,9 \% обследованых. 27,5 \% больных ГЭРБ были инфицированы H. pylori.

Выводы. 1. Установлено, что эндоскопически негативная форма ГЭРБ в 4 раза чаще диагностируется у женщин, тогда как эрозивные изменения слизистой пищевода вдвое преобладают среди лиц мужского пола. Выяснено, что чаще всего ГЭРБ диагностировали у лиц молодого и среднего возраста (48,1 и 19,1 \% соответственно).

2. Показано, что факторами риска развития ГЭРБ являются нерегулярное питание и курение. Зато хеликобактерная инфекция не ассоциируется с ГЭРБ независимо от эндоскопической картины.

3. Установлено, что ежедневная изжога, тошнота и неприятный привкус чаще встречаются у пациентов с эндоскопически негативной ГЭРБ $(55,6,62,9,77,7$ \% соответственно), сочетание периодической изжоги, отрыжки и боли в эпигастрии позволяет заподозрить наличие эрозивно-язвенных изменений слизистой оболочки пищевода.

КЛЮЧЕВЫЕ СЛОВА: гастроэзофагеальный рефлюкс; клинические проявления; хеликобактерная инфекция.

\section{FEATURES OF THE CLINICAL COURSE OF GASTROESOPHAGEAL REFLUX DISEASE IN THE LVIV REGION}

@M. Yakhnytska

\author{
Danylo Halytskyi Lviv National Medical University
}

SUMMARY. Gastroesophageal reflux disease is the most common pathology of modern gastroenterology, which causes significant economic and social damage, affects the quality of life of people.

The aim: to investigate the clinical course of gastroesophageal reflux disease.

Material and Methods. A questionnaire, an endoscopic examination of the upper gastrointestinal tract, and a sito test ${ }^{\circ}$ H. Pylori Ag from Pharmasco $®$ for the diagnosis of helicobacter infection were conducted.

Results. The results of observations on 102 patients with GERD were analyzed: 48 (47.1\%) women and 54 (52.9\%) men. The average age of women was $(48 \pm 2.11)$ years, men $(37.7 \pm 1.65)$ years. In $73.5 \%$ of the examined patients, the endoscopically positive form of GERD was diagnosed, while $26.5 \%$ had no erosive-ulcerative changes in the esophagus mucosa. Study of lifestyle communication in patients with GERD showed that irregular nutrition and smoking contribute 
Огляди літератури, оригінальні дослідження, погляд на проблему, ювілеї

to the development of the disease. Analysis of the main complaints showed that in $37.2 \%$ of patients with heartburn, daily, periodic heartburn 3-4 times a week was noted by $62.7 \%$ of patients. Bloating and morning vomiting were observed in $59.8 \%$ and $16.7 \%$ of patients respectively. Nausea was noted by $37.2 \%$ of the surveyed. An unpleasant taste in the mouth complained $35.3 \%$ of patients. Epigastric pain was observed in $53.9 \%$ of cases. $27.5 \%$ of patients with GERD were infected with $\mathrm{H}$. pylori.

Conclusions. 1. It was established that the endoscopically negative form of GERD is 4 times more often diagnosed in women, while erosive changes in the mucous membrane of the esophagus are twice as high among males. It was found that most often GERD was diagnosed in young and middle age (48.1\% and $19.1 \%$ respectively).

2. It was shown that the risk factors for GERD are irregular diet and smoking. Instead, the helicobacter infection is not associated with GERD, regardless of the endoscopic pattern.

3. It was found that daily heartburn, nausea and an unpleasant taste are more common in patients with endoscopically negative GERD (55.6 \%, $62.9 \%, 77.7 \%$ respectively), a combination of periodic heartburn, burping and pain in the epigastrium can be suspected of having erosive-ulcerative changes in the esophagus mucosa.

KEY WORDS: gastroesophageal reflux; clinical manifestations; , helicobacter infection.

Отримано 28.01.2019 